\title{
Globalizing Globalization: The Neo-Institutional Concept of a World Culture
}

\author{
DANIEL TRÖHLER
}

The history of education in relation to globalization is quite paradoxical. The first global phenomena of education emerged out of reactions against the Reformation in the late sixteenth century, when the Counter-Reformation Jesuits, or Society of Jesus, started to establish institutions of higher education, first in Europe and later in other parts of the world. Provided in architecturally standardized buildings, the Jesuit education was based on a standardized curriculum developed by international experts ${ }^{1}$ and used standardized quality rating systems to assess students' achievement (see, for instance, Dainville, 1978). The historiography of education in relation to globalization can be called a paradox because it does not focus on this successful CounterReformation concept but rather, quite to the contrary, on the alleged spread of mostly secularized Protestant concepts. It is these Protestant concepts that-according to the historiographic accounts-have been diffused around the world since at least the end of the Second World War, constituting through a "cultural globalization" process a new "world culture" in which specific patterns of thoughts are brought about by transnational organizations and international experts. One definition of this process reads as follows: "Cultural globalization involves the worldwide spread of models or blueprints of progress and the networks of organizations and experts that transmit these logics of appropriateness to nation-states and other collectivities" (Suarez \& Ramirez, 2004, p. 1). Educational expectations and organizations play a crucial role in this process. According to these interpretations, educational systems were the crucial means used in "developing the Western Europe model of a national society" (Ramirez \& Boli, 1987, p. 3) that, even though transcended in the twentieth century, has not diminished the importance of education; quite the contrary.

"Globalization" is a concept that refers to an encompassing process with radical effects, similar to concepts such as Christianization, confessionalization, secularization, or modernization. All of these notions serve to indicate fundamental theories describing these encompassing 
processes. However, when describing processes of this amplitude, the description is always a construction, too. This construing description has its pitfalls. The main danger is linearizing and harmonizing the process, starting out from its alleged result: Christianity, schism, secularity, modernity, or the globalized world. ${ }^{2}$ Following the normative preferences of the authors, these descriptions tell either a story of decline or a story of success. Famous stories of success were written, for example, by the British Whigs in the eighteenth and nineteenth century, depicting the past as an unavoidable and thus teleological progression towards always greater individual liberty and enlightenment, resulting in modern forms of liberal democracy, constitutional monarchy, and scientific progress-in other words, to the dominant ideology of Whiggism in England. In order to criticize this goal-directed, often hero-based historiography, the British historian Herbert Butterfield published the celebrated book The Whig Interpretation of History in 1931 (Butterfield, 1931) and, ever since, the notions of Whig history or Whiggishness have been used to criticize teleological accounts of the past to the present.

In the following I will focus on how globalization and education are addressed in research. More precisely, I will concentrate on only one dominant approach to analyzing globalization and its effects on education and also the educational role within globalization. Although my focus is quite narrow and apparently analytic, I still do not imagine that I am refraining from talking about globalization and education, for the international discussion about globalization is itself a part of the process. $^{3}$ Nevertheless, I wish to analyze a model that seems to provide a basically analytical account of globalization with respect to education, the model called sociological neo-institutionalism, and its concept of world polity or world culture. This is an area of research that emerged mostly at the Department of Sociology and the School of Education at Stanford University. These analyses have garnered a lot of attention, and they are broadly discussed and refined all around the world in a number of different academic disciplines.

Basically, using the example of the sociological neo-institutional contribution to globalization and education, I will demonstrate how difficult it is to analyze or describe the process of "globalization" without premises that first construe the topic itself that is going to be described. In other words, the analysis of encompassing historical processes such as "globalization" is already predetermined by general epistemological assumptions in the research design. These epistemological premises in sociological neo-institutionalism are-as I will 
argue-rooted in Max Weber's Protestant ethic thesis. This origin is particularly juicy for neo-institutionalism, for its sociological paradigm is the result of a critical examination of Max Weber's theory of institutions. My thesis is that, with the background of Max Weber's Protestant ethic thesis, sociological neo-institutionalism interprets globalization as a more or less linear process, and the analysis becomes thus a part of the grand narrative of Protestantism itself. ${ }^{4}$ I will demonstrate my thesis in four steps. First, I depict sociological neo-institutionalism and its contribution to the analysis of globalization. In the second part of the chapter I discuss the problems of analyzing historical processes. In the third part I show how linear constructions of a global history frame our view of the institutions of education, and finally I discuss how we can deal with the problem of analyzing globalization without construing it at the same time.

\section{Education and the World Culture Thesis of Neo-Institutional Sociology}

About 30 years ago the educational discourse was confronted with a conceptual distinction developed at the Department of Sociology at Stanford University on the basis of studies of educational establishments. The distinction reformulates Max Weber's concept of the institution by differentiating "institution" from "organization." The inspiration for this distinction was borrowed from a model developed in organizational psychology, the notion of "loose coupling," which describes the relation between the formal structures of and the inner activities within an organization (Glassmann, 1973; Weick, 1976). When this model, developed within organizational psychology, was looked at from a sociological point of view, the idea arose that these formal structures of an organization (such as the school) are a result of adjustment processes. These adjustment processes are interpreted to be triggered by institutionalized social and cultural expectations in order to provide the organization with legitimacy - in other words, to allocate the required resources to the organization. The loose coupling model in sociology thus describes the fact that these formal structures of organizations are not tightly linked to the practices of production of the organization. These inner activities are believed to have-regardless of public legitimacy - a logic of their own in terms of effectiveness and efficiency (Meyer \& Rowan, 1977, pp. 341-343, 361; see also Meyer \& Rowan, 1978, pp. 79-81). Historical case studies in education endorse the idea that the phenomenon of loose coupling is not only not a 
disturbing factor but quite on the contrary also a constitutive factor of an educational organization; indeed, attempts to connect formal structures and inner activities tightly can lead to an annulment of the organization (Bosche, 2008; Tröhler, 2009b). In other words, cultural expectations are mirrored in the formal structures and procedures of organizations such as schools, whereas the inner activities such as teaching are hardly affected by these organizational strategies-much to the chagrin of educational reformers.

Shortly after having presented this fruitful and, to a certain degree, non-historical sociological interpretation of the loose coupling model, the authors started to expand it. At first glance, the expansion was primarily geographical, for now global (rather than local or national) tangible structures of education were analyzed. But the expansion of the model was not only geographical, for it aimed at explaining long-term processes. The expansion became historical. The analysis of these processes in the period of the last 150 years led the scholars to posit the growth and enactment of a world culture, in which the world has become an "international society" or a "world polity" (Boli \& Thomas, 1997; Meyer, 1980). They argued that, since at least the middle of the nineteenth century, a rationalized world institutional and cultural order has emerged which consists of universally applicable models that shape states, organizations, and individual identities (Meyer, Boli, Thomas, \& Ramirez, 1997, p. 173). In order to write this kind of history of the emergence of a world culture, the authors relativize the traditional assumption according to which the school systems of the nation-states of nineteenth-century Europe, on the one hand, and the global structured schools of today, on the other hand, are incompatible to a large degree. In a paper on historical and comparative education, Meyer and Ramirez (2000) claim that as a rule the functionality and singularity of the national education systems of the nineteenth century are overestimated to a large degree. They point to a lot of transnational similarities, despite the fact that the national education systems became institutionalized in the national societies based on nationalistic agendas (see also Ramirez \& Boli, 1987).

This historical and comparative interpretation led to the conclusion that the nation-states, these "imagined communities" (Anderson, 1983) with their educational systems as core means of these constructions, did not emerge mainly from "internal" ideas but rather were framed by "cultural principles exogenous to any specific nation-state and its historical legacy" (Meyer \& Ramirez, 2000, p. 115) that exert pressure on the national educational systems. Due to this pressure, Meyer and 
Ramirez continue, the national educational systems are not as much tied to new and very different idiosyncrasies of social realities as they are homogenized by common aims and projects of development and by shared technological visions to achieve the aims (p. 116). The process of homogenizing and standardizing became faster through technological means and organized international networks of communication: "The professionalization and scientifization of education greatly speeds up worldwide communication and standardization, just as the latter clearly facilitates the former. These processes reciprocally influence and strengthen each other" (p. 118). They are described to be isomorphic in the results (p. 127), fostering the worldwide formal adjustment of the national educational systems.

The leading ideology of this transnational process was accompanied by universalization of the notion of development. Whereas for a long time the concept of "development" was applied primarily to the so-called Third World states in order to outline their duties toward the First World, in the 1970s development became the core concept of modernity par excellence. In other words, all countries had to develop in order to guarantee global survival (Hüfner, Meyer, \& Naumann, 1987, pp. 194-197). ${ }^{5}$ Therefore, the cultural self-understanding of modernity is the permanent task of continuous self-development, a task that depends heavily on education, or the educational system. Although doubts have been raised about the connection between the establishment and development of the educational system and the economic, social, and political development, belief in this connection has become accepted all over the world (Chabbott \& Ramirez, 2000). In other words, the world society requires both the nation-state and its overcoming in the age of globalization (Meyer, Drori, \& Hwang, 2006), whereas belief in the agency of the educational system has been handed over from the ideal of the national to the global society without being altered in its importance.

Globalization is defined here as the "diffusion of cultural practices and commodities-from consumption of media like TV programs and Hollywood movies to norms like human rights and environmentalism" (Drori, Meyer, \& Hwang, 2006, p. 11), which in turn exposes a need for adjustment in the single national societies. Meyer et al. (1997) state:

World-society models shape nation-state identities, structures, and behavior via worldwide cultural and associational processes. (...) As creatures of exogenous world culture, states are ritualized actors marked by extensive internal 
decoupling and a good deal more structuration than would occur if they were responsive only to local, cultural, functional, or power processes. (p. 173)

According to sociological neo-institutionalism, the world society is primarily a cultural phenomenon that arose historically, and international organizations such as the United Nations, the United Nations Educational, Scientific and Cultural Organization (UNESCO), or the World Bank founded in the wake of the Second World War have played a crucial role in establishing this globalized culture:

The colossal disaster of World War II may have been a key factor in the rise of global models of nationally organized progress and justice, and the Cold War may well have intensified the forces pushing human development to the global level. (Meyer et al., 1997, p. 174)

The crucial epistemic question remains as to whether processes like globalization can be described analytically at all, or how far sociology or history themselves contribute to the construction of their own object that is allegedly simply being described.

\section{Sociology and the Temptations of History}

Complementary historical and sociological explications of developments of organizations such as schools are not only academically desirable but also a desideratum of educational policy and of all efforts that are subsumed in the notion of school development. However, the complementary harmony between history and sociology has been from its beginnings more wishful thinking than artifact, if we only think of Émile Durkheim's Preface to his journal Année Sociologique, in which he evaluated the academic character of history with the standards of sociology:

History can be an academic discipline only to the extent that it explains, and it can explain only by comparing. (...) But then, from the moment it compares, history becomes indistinguishable from sociology. (Durkheim, 1898, p. III; freely translated here.)

The great interest of sociology in history is no coincidence, for history provides an inexhaustible potential of empirical facts. However, Durkheim's hierarchy in terms of academic standards is problematic, because sociology is tempted to argue historically, but not to use standards developed in academic history but rather its own standards. 
Sociological neo-institutionalism relies largely on such an historiography, namely, on the historical reconstruction in Max Weber's study, published first as essays in 1904 and 1905, Die protestantische Ethik und der "Geist" des Kapitalismus (The Protestant Ethic and the Spirit of Capitalism) (Weber, 1930) — a prime example of a history construed by a rather a-historical sociology of religion. In this eminent study Weber transposes the German Lutheran concept of Beruf (occupation) into English Calvinism and by that creates a peculiar Lutheran interpretation of Anglo-Saxon Calvinism. It is this Lutheran/Calvinist amalgam that led to Weber's dilemma in religion policy, for despite his deep sympathy with Luther, Weber showed more respect for the Calvinist culture. The main theoretical problem with this blending is that Luther and German Evangelical Protestantism insist on a dualistic, two-kingdom doctrine. According to the doctrine, in the one kingdom Christ rules through word and sacrament, mercy and forgiveness are practiced, and there are no differences among people. In the other kingdom, in contrast, the Emperor reigns with the sword, and there is no mercy and no equality. But to Luther the worldly kingdom still has a purpose in that, namely, the prince curbs the evil in men-even if through violence, peace is established, and thus conditions are created for proclaiming the Gospel (Luther, 1523/1983, pp. 41-44). Logically, ideas like political participation, which is a core characteristic of the Baptist church and of Congregationalism, are foreign to Lutheranism. This political indifference of Lutheranism makes it understandable that, whereas Weber focused on the Anglo-Saxon Calvinist theory of work, he neglected its political theory of participation. Indeed, this culture is not inherent in original Calvinism but was developed by the English Baptist and Congregationalist sects in the seventeenth century in the light of the dominant Anglican Episcopal Church in which the suppressed Protestant sects had to fortify the role of the community and the concept of participation. ${ }^{6}$

To date the sociological research has hardly recognized that Weber's Lutheran interpretation of Anglo-Saxon Calvinism has eclipsed one core element of the latter, namely, the fundamental local democratic culture, and by doing so it has at the same time prescinded the alleged lone Calvinist citizen. This Weberian pattern seems to stand in the background of the (re-)construction of the idea of a world culture, too. For if neo-institutional analysis presumes that the nationstates of the nineteenth century were less unique and much more exposed to transnational pressures than one would think, the question arises as to where the transnational or universal ideas originate. 
Neo-institutionalists address this task by going back to the time that is usually labeled the Renaissance, a cultural epoch superseding what are called the Middle Ages and breaking the path to modernity. ${ }^{7}$ Again, it is Max Weber who provides the starting ground, namely, Weber's thesis of the rationalization of the world. ${ }^{8}$ In an article on "Ontology and Rationalization in the Western Cultural Account," Meyer, Boli, and Thomas (1987), with their concept of "world culture" in mind, understand the structuring of daily life as following standardized and impersonal rules; these rules constitute the social order as a means to achieve collective aims such as progress and justice. In this respect, Meyer, Boli and Thomas (p. 20) interpret the establishment of a world culture as a matter of a millennium project of the Western world, in which actors and actions are examined through universal lenses that are hardly recognizable as general rules and that are very effective precisely because they are hard to recognize (p. 19).

In the same way that Max Weber argued, Meyer et al. (1987) state that the beginning of this development is situated in first universal structure to exist, namely, in the Western church:

The institutions of the West devolve from Western religion and the church at least as much as they are built up by the strategies of subunits. (...) The frame derives directly from the Christian church and the invisible conceptual 'Kingdom of God' that the earthly church organization was supposed to represent in an imperfect way. (p. 23)

It is interesting to see what the authors mean by the "Western religion and the church" that allegedly were at the origin of the millennium project. Obviously, the authors are in a dilemma. On one hand they foster the idea of an early global idea, and on the other hand they identify the Reformation (of all things) in the first quarter of the sixteenth century as the initial point of this peculiar development towards world culture. This, in turn, means seeing (church) schism as the beginning of a process of global standardization. Against that background, the historical source is blurred rather than identified. On one hand, a date is named that lies some years abead of the Reformation, namely, "perhaps 1500" (Meyer et al., 1987, p. 23), when according to the authors the church had been "transnational" and able to comprise a multitude of cultures symbolically. The church had been universalistic in its duty to bring "the way, the truth, and the life" to the whole of humanity. On the other hand, the authors emphasize that the "power of the Word" had been extremely important in the church's evangelic attempt, which as a matter of fact would unmistakably be a Protestant 
interpretation; the holistic Catholic universalism of the late medieval times (or very early modern period) is being interpreted through Protestant lenses. What remains to be analyzed is: through the lenses of which Protestantism?

According to sociological neo-institutionalism, it was the expansion of Christianity that had prepared the way for the dissemination of universalistic ideologies with highly legitimated, boundary-less polities. It is precisely within this process that the modern "cultural" culture with its crucial means of the education system arose (Meyer et al., 1987, p. 23). In an article co-authored with Ronald Jepperson, Meyer argues how within the expansion, the development, and the secularization of Christianity the concept of agency altered. In the beginning, agency was ascribed to transcendent powers, and little by little it was transferred to society and the individual person as the "authorized agency" (Meyer \& Jepperson, 2000, pp. 101f.). Here it is interesting that the authors, in only two pages, jump from the alleged universal world of "perhaps 1500 " with its feudal system, to the ideology of technical progress and the sacred meaning of the nation-state in the nineteenth century with its educational system, and then to Bretton Woods and the founding of the World Bank, one of the crucial transnational organizations in the process of globalization. Here they leave little space for alternative concepts and counter-movements, and do not trace the questions as to how in a universal culture the idea of a nation-state became possible, how the school became the church of the (sacred) nation in the nineteenth century, and how the different denominations influenced the cultural understandings of the school systems (Meyer et al., p. 23). According to Ramirez and Boli (1987), "despite much variation in level of industrialization, class structure, and political regime, the ideological and organizational responses [mass education] of the various countries to challenges to state power were strikingly similar" (p. 9). This, of course, is a matter of the level of interpretation. At a very abstract global macro level, this interpretation might be convincing, and it fits in nicely with the idea of a global vision of universalism spreading around the world.

It is significant that an examination on a more meso level challenges the persuasiveness of this global interpretation. A comparison between the upper secondary education curricula in Prussia and Switzerland in the nineteenth century reveals a different picture. First, there appear to be striking transnational similarities with regard to both the formal differentiation of the upper-secondary education into types and the development of the curriculum (focusing mainly on the introduction of 
modern foreign languages). However, another picture appears if methods of historical contextualization are used. First, the contextualization of the curriculum within the overall organization of the school system raises doubts as to whether the similarity between the two countries is more than only quantitative on a very abstract level. The second contextualization of the overall organization of education within cultural convictions not only makes this even more doubtful but also reveals fundamental differences rooted in different political convictions, such as monarchism and republicanism (and German Lutheranism and Swiss Calvinism). The result of the comparison shows that, despite some formal similarities, the establishment of foreign language education in Switzerland and Prussia could not have been more different (Tröhler, 2009a). The point is that by abstracting from all cultural idiosyncrasies, it cannot be really surprising that a school is a school and that therefore they all appear to be similar.

The Linear Construction of a Global History and the Institutions of Education

The religious history serving the construction of the neoinstitutional account of globalization is little differentiated and does not discuss explicitly the church schism of the sixteenth century, even though it is focused on the Reformation, and it does not pay sufficient attention to the different denominations within Protestantism and their respective development. The neo-institutional interpretation of Calvinism with the sacred individual as agent (besides the organization and the nation-state) is owed to Max Weber's Lutheran interpretation of Calvinism. When the authors of this interpretation start their historical account at "perhaps 1500," they do not claim that the globalized world culture in fact arose out of the Western church. It becomes evident that they are talking about Protestantism, more precisely about Calvinism that had become transformed in seventeenth-century England-in other words, the line of Calvinism that was already Weber's focus and to which he attributed the Lutheran concept of profession. Meyer and Jepperson (2000) refer explicitly to "Anglo-American" Protestantism without precisely distinguishing it from a "German and Scandinavian" tradition; they simply state that this latter tradition is "more corporate," while the Anglo-American tradition is supposed to be more individual (p. 108).

The fact that Anglo-American Calvinism and Lutheranism differ greatly in the idea of the political order and the concept of the citizen is 
not considered at all. Still today, Bürger in German means something completely different from "citizen" in U.S. American, as perplexed scholars in international comparative citizenship education have to admit. And whereas in some countries small efforts in citizenship education are very effective, in other countries, such as Germany, few of the desired effects are achieved, despite high investments. The low results are hard to explain: "Whether they are rooted in culture, history, or some aspect of schooling is not evident" (Hahn, 1999, p. 247). Neglecting these fundamental religious/cultural distinctions, Meyer and Jepperson (2000) believe in American individualism, losing sight of the fact that local democracy is the ideological counterpart of this individualism, setting boundaries to excessive individual liberalism-an ideological source, by the way, that stood at the beginning of the educational philosophy of pragmatism. The social culture emerging from this ideology was not least appreciated by Max Weber when he visited the United States in 1904. Weber's wife, Marianne Weber, wrote that her depressive husband recovered when he shared the social culture in the United States: "Weber could hardly wait for the landing procedures and customs inspection; he strode from board ship with long, bouncing steps-leaving his faithful companion behind-like an eagle set free that can finally take to the sky" (Weber, 1950, p. 318; freely translated here). And then, describing the culture: "The whole magic of memories of youth lies alone just in this time of life. Lots of sports, pleasant forms of social activities, endless intellectual stimulation, and long-lasting friendships are the yields, and especially, far more so than our students, they are trained in the habit of work." And at the end of their American travels, she reported: "This faithful companion sometimes has the feeling that she is bringing home a man who has recovered, who has become conscious of a slowly gathered stock of strength" (p. 345; freely translated here).

However, despite his personal experiences, Weber continued to interpret Calvinism as essentially individualistic without paying attention to its democratic local basis, and neo-institutional sociology seems to follow this crooked interpretation by defining this model as the basis of the American liberalism that eventually became successfully disseminated around the world after Second World War and that dominates contemporary world culture. In it the agent as that "abstract, rather contentless, entity in social space" is being legitimated (Meyer \& Jepperson, 2000, p. 109). In accordance with Max Weber, the neoinstitutional interpretation identifies an isolated individual as the result of Calvinist Protestantism having become the rationalized agent of the 
globalized process. However, by following a Lutheran interpretation of Anglos-Saxon Protestantism and its triumphant history, the historical account becomes itself part of this Whig history.

It is true, of course, that the democratic dimension in Anglo-Saxon Calvinism is universal in terms of its religious foundation, but the point is that this universal claim is foreseen to be materialized locally. Within this tradition, democracy is embodied locally, and the local traditions are distinguishable and, precisely, not standardized. But like any other fundamental theory about historical processes, the neo-institutional reconstruction of globalization pays little attention to challenging concepts, cultural idiosyncrasies, and the contingency of the process, for the glory of making complexity look logical. Weber's philosophy of history is rewritten and expanded in order to explain the emergence of a world culture, ignoring the taken-for-granted assumptions, the culturally anchored convictions, in other words, the institutions of the localism that nota bene had been the topic of the early neo-institutional studies with which this area of research was able to become established. This may be the reason why little attention is paid to the tensions between a global culture and a local culture, each of them sharing expectations about schooling. The fierce reactions to PISA in Germany, for instance, are due to a cultural clash between the national taken-for-granted assumptions about education and the transnational agenda of an international organization such as the Organization for Economic Co-operation and Development (OECD) (Overesch, 2007; Weigel, 2004). And in Switzerland, where schools are governed by the individual cantons and the school laws have to be put to the ballot, educational reform proposals following an international agenda are turned down by the local or regional sovereigns. Recently, even a not really far-reaching attempt to harmonize (for the very first time) the duration and some basic aims of the elementary schools in Switzerland (HarmoS) was rejected by some of the Swiss cantons.

The organizational expressions of this locally defined democracy within education are the already local and regional school boards in the United States, in some provinces of Canada, and in Switzerland-thus, in those regions of the world dominated by a modified Calvinist religion. ${ }^{9}$ It is these that make out of a state school a public school, a distinction that is usually not broadly recognized. It is this localism that reinforces the stability of the inner activities of organizations such as the school, or the grammar of schooling, as David Tyack and others have said (Tyack, 2003). If the school is primarily subject to the local public instead of to the centralized administration, the caution shown towards 
reforms is greater, because communal responsibility does not gamble lightly with proven quality. It is no coincidence that the transnational culture of experts conflicts with the local logic of school governance. The constant accusation that the local school boards are the major cause of failing reforms signifies the dramatic clash between the idea of an elite democracy and the local democracy, or between expertise and common sense. ${ }^{10}$

These local cultural expressions are not the focus of sociological neo-institutionalism. They seem to disappear altogether or to take the role of agents, losing their character of agency in the course of the globalization process. However, within the Weberian-inspired historical theory of rationalization and Weber's Lutheran interpretation of Calvinism, phenomena will be perceived to fit into the encompassing historical process leading to the world culture. The alleged empirical evidence of the processes that seems to be the source of the theory of globalization is itself a consequence of a universalized interpretation of Protestantism that has been taken for granted. The historical particularity has thus become a universality, a frame that would allow no empirical evidence to be different other than to support the general thesis of globalization. The (alleged) description of the object turns out to be, in the end, the construction of the object. Insofar as this (re-) construction serves the interpretation of the universalized self (perception), we can recognize a new example of Whiggism. Is there an alternative?

\section{Research in Globalization and Education}

It is not difficult to find evidence of pro and con arguments regarding the globalization thesis of sociological neo-institutionalism. Leaving cultural idiosyncrasies of the school systems aside, there $i$ a history of globalization leading to a more or less homogenous world of education, and focusing in contrast on historical particularities raises doubts about this history. The French do center on political symbols in citizenship education, and the British do not (Hahn, 1999). However, this kind of argument might not pay attention to the main problem discussed here. The problem is how to deal with phenomena without being part of them.

Classical scientific epistemology used the word "objectivity" to surmount the problem, but we know today that paradigms not only suggest certain solutions of the problem but indeed actually construe the problem, and any successful paradigm will reduce history to its own 
success, widely ignoring other paradigms (Kuhn, 1962). As there seems to be no Archimedean point from which we can perceive the subject of inquiry objectively, the inquiry needs to address the researcher as well-not in order to eliminate the researcher's own world view and epistemological frame but in order to become aware of it. I see no other way than to historicize not only a topic but the construer of the topic as well. One of today's leading historians, Quentin Skinner, said not without reason that one of the big advantages of studying history is not only the acquisition of knowledge but also the acquisition of selfawareness: "To learn from the past-and we cannot otherwise learn at all ... is to learn the key to self-awareness" (Skinner, 1988a, p. 67). "Doing history" is essentially the discovering of one's own standpoint. From a historiographic point of view, the critical question discussed in this chapter is not how do we explain our global hegemony historically, but why and how we ourselves help to construe a history framed as a triumphant history (or a history of decline). Discussing the quest that a historian should be able "to discount or set aside the fact that he or she holds certain beliefs to be true and others false," Skinner (1988b) answers: "I am sure no historian can ever hope to perform such an act of forgetting, and that in any case it would be most unwise to try" (p. 236).

The act of forgetting would be unwise because it would homogenize the researchers with their topic, in other words meld the construction of the object with the research on it; again, the result is then a form of Whiggish history. One way out of this dilemma was John Pocock's suggestion to analyze the languages in which topics are discussed. History, Pocock (1987) says, always deals with transmissions of "acts of speech, whether oral, scribal or typographical" that depend on "the conditions or contexts in which these acts are performed" (p. 19). In accordance with Saussure (2006), Pocock indicates that political actors have always depended (and still depend) on a langue to perform a speech act: "For anything to be said or written or printed, there must be a language to say it in; the language determines what can be said in it, but is capable of being modified by what is said in it; there is a history formed by the interactions of parole and langue" (Pocock, 1987, p. 20).

Political and educational languages are modes of thought; not political slogans or concepts, but specifically used rhetoric and vocabularies, and they are identified to be the ideological context of any political and educational parole. Two things are important. First, by virtue of their normative structures framing the actor's parole, languages are deeds: they construe in a normative way what is perceived as social reality. And second—and this refers again more to Thomas Kuhn—several langues 
always exist at the same time, whereas one is always dominant. In other words, every epoch has its dominant mode of perceiving, analyzing, and discussing political phenomena, and it also has alternative modes that just do not dominate. These dominances do not alter unless deep crises occur that cannot be described in an appropriate way by the dominant langue, thus making that solution seem to be impossible. At these moments people can resort to another langue that seems to describe the circumstances in a more appropriate way. The new langues then become dominant, without erasing the former dominant langue (Pocock, 1962, p. 195; Pocock, 1987, p. 21f.).

If we only take a look at the period from the eighteenth century to the present, we can distinguish a number of paradigms that could be labeled educational languages (see Tröhler, 2009c), but the number is certainly limited. These educational languages are closely connected to visions of justice, happiness, and progress, and to the idea of the child and the citizen. The oldest language that survived the transformations after the Renaissance-at least to a certain degree-is the classical republican language based on public virtues and political freedom. This classical language that was formulated by Aristotle or Xenophon was reinforced and modified first by Machiavelli (Pocock, 1975) and almost at the same time by the Swiss Reformation, that is to say, by Calvin and Zwingli, with their inestimable influence on the idea that social problems are to be solved primarily by education (Tröhler, 2008). The focus is on the citizen of the polis as a concept, including the political, religious, economical, and military aspect of life in one person. Another old language that survived the transformations of eighteenth century lies within the Augustinian and Neo-Augustinian tradition. This language was especially attractive for educational questions in the antiJesuit movement of Jansenism, which found its most important stronghold in the Parisian convent of Port-Royal, haven of many important authors such as Antoine Arnauld, Pierre Nicole, and Blaise Pascal, all of them self-identified as rigorous followers of St. Augustine (Carraud, 1992) and all of them focusing on the insignificance of human life. Many of these important authors were widely received in specific traditions of education, especially in the German concept of Bildung, that originated in Luther (Luther being an Augustinian monk) (Horlacher, 2004; Osterwalder, 2003, 2006). It is these two languages that got mixed by Weber unintentionally, for he believed his interpretation was an analysis of Calvinism. A third educational language is the child of the late eighteenth century, more precisely of the French Revolution. Having its roots in the early modern sciences in England, it 
was developed into a specific form of educational language by Condorcet or Destutt de Tracy after 1790 (Osterwalder, 1992). Unlike the two others, this language builds essentially on academic knowledge and the public rationality effectuated by this knowledge. The ideal human being is not the contemplative person having found peace in his inner soul, as in the Neo-Augustinian tradition, nor the fully virtuous patriotic citizen, as in the classical republican tradition, but rather an individual person that is interconnected with other persons by a social contract based on rational deliberation and decision.

The historical analysis of a process of globalization that will minimize the construing of the topic will have to analyze the adaptability of the single languages, their connection to religious and/or political languages, and the hybrid forms that they receive in specific historical constellations. Isomorphic structures will then not be the center of research but rather patterns of thoughts and the adventure of their cultural diffusion. And we should not forget that Christianity is not the dominant religion in the world, that Protestants make up not even 10 percent of the world population, and that Christianization is not only the story of the missionaries but also of those being evangelized, as Jacques Gernet (1985) showed in his wonderful book, China and the Christian Impact: A Conflict of Cultures. There is ample empirical evidence that the dominant culture in the world today is a dominant one among others, and that historical accounts of the triumphant story will cement the position only at the price of neglecting others.

\section{AUTHOR's NOTE}

An earlier version of this paper was presented at the Institute of Sociology at the University of Zurich, May 9, 2007. I wish to thank Thomas S. Popkewitz for his amicable and stimulating help in shaping this chapter.

\section{NOTES}

1. The procedure was dogmatic and pragmatic at the same time. First, in 1586 a committee of six experts from Spain, Portugal, Scotland, Flanders, Holland, and Sicily developed a draft of a course of study, which was then sent for comments to teachers all over Europe. A reformulation of the course of study based on the feedback received was sent out again for annotations. The result of this consultation was the (probably most successful) global curriculum, the Ratio atque Institutio Studiorum Societatis Iesu, published first in 1599 and remaining unchanged until the nineteenth century. For further details, see Donnelly (2006).

2. Thomas S. Kuhn detected this tendency in the history of science. After a paradigm shift has occurred, Kuhn says, the protagonists of the new paradigm write histories of the paradigm as if science could have not taken any pathway other than to the new state of the art. In doing so, they neglect, suppress, and marginalize competing paradigms (Kuhn, 1962). 
3. Globalization is not only discussed as a distinct topic in the Western sphere by Western intellectuals, but has also become a global phenomenon in the academic discursive performances themselves. See, for instance, Khondker (2000).

4. For one of the famous (postmodern) critiques of the grand narratives, see Lyotard (1979/1984).

5. As a matter of fact, the idea goes back to the Cold War in the 1950s, and it influenced educational notions, especially those of the World Bank and the OECD (see Tröhler, 2010).

6. See, more broadly, Tröhler (2006). Calvinism in Scotland, in contrast, was broadly enforced, so that Scottish Calvinism-Presbyterianism-was not forced to develop a fundamental theory of democratic participation.

7. When exactly the epoch of the Renaissance starts, and when it ends, is a matter of dispute. In contrast to art historian Jacob Burckhardt, the "father" of the notion of the "Renaissance," Burke takes the example of the supposed "end" of the Renaissance to show that it would be more accurate to think in terms of a dissolution of the various Renaissance arts-painting, philosophy, music, or architecture-that was successive but that varied in the speed with which it took place in the different European countries (Burke, 1987, p. 81). It is also impossible, Burke concludes, to speak of a clearly identifiable "start" of the Renaissance, which-according to Burckhardt's thesis-marked the end of the Middle Ages and recognized, for the first time, the person as an individual identity.

8. "By 'rationalization' we refer (conventionally) to the cultural accounting of society and its environments in terms of articulated, unified, integrated, universalized, and causally and logically structured schemes." (Meyer \& Jepperson, 2000, p. 105, footnote 5)

9. In the mentioned provinces of Canada it was American settlers who brought the tradition of the school boards with them, for instance to Alberta. In Switzerland it was Zwinglianism, reforming Calvinism towards more democracy.

10. It does not occur without reason that educational policy makers, experts in think tanks, and professors attracted by the alleged opportunity to reform schools are irritated by the existence of local democratic control of the school and that they accuse the school boards of hindering reform and sustaining the persistence of the status quo. In the view of the expert-driven democracy emerging at the beginning of the Cold War, democracy works essentially not locally but as a form of competition among elites for votes, and therefore democracy is reduced to its procedural function of election. Not even high voter participation in elections was sought after, far from it: "That democracy is best, in which people participate least," was the general assumption of the expertise-driven democracy in the 1950s (quoted in Gilman, 2003, p. 48).

\section{REFERENCES}

Anderson, B. (1983). Imagined communities: Reflection on the origin and spread of nationalism. London: Verso.

Boli, J., \& Thomas, G.M. (1997). World culture in the world polity. American Sociological Review, 62(2), 171-190.

Bosche, A. (2008). Loose coupling als konstitutives Element der Organisation von Schule: Das Fallbeispiel Haldenstein-Marschlins in der Schweiz des 18. Jahrhunderts. In M. Göhlich, C. Hopf, \& D. Tröhler (Eds.), Persistenz und Verschwinden. Pädagogische Organisationen im bistorischen kontext (pp. 69-81). Wiesbaden: VS Verlag.

Burke, P. (1987). The renaissance. Atlantic Highlands, NJ: Humanities Press International. Butterfield, H. (1931). The Whig interpretation of history. London: Bell.

Carraud, V. (1992). Pascal et la philosophie. Paris: Presses Universitaires de France. 
Chabbott, C., \& Ramirez, F.O. (2000). Development and education. In M. Hallinan (Eds.), Handbook of the sociology of education (pp. 163-187). New York: Kluwer Academic.

Dainville, F. de (1978). L'éducation des fesuites (XVI-XVIIIe siècles). Paris: Les éditions des minuits.

Donnelly, J.P. (2006). Jesuit writings of the early modern period, 1540-1640. Indianapolis, IN: Hackett Publishing Company.

Drori, G.S., Meyer, J.W., \& Hwang, H. (2006). Introduction. In G.S. Drori, J.W. Meyer, \& H. Hwang (Eds.), Globalization and organization (pp. 1-22). Oxford: Oxford University Press.

Durkheim, E. (1898). Preface. Année Sociologique 1896-1897, (1), I-VII.

Gernet, J. (1985). China and the Christian impact: A conflict of cultures. Cambridge: Cambridge University Press. (Original work published in French 1982.)

Gilman, N. (2003). Mandarins of the future: Modernization theory in Cold War America. Baltimore: Johns Hopkins University Press.

Glassmann, R.B. (1973). Persistence and loose coupling in living systems. Behavioral Science, 18, 83-98.

Hahn, C.L. (1999). Citizenship education: An empirical study of policy, practices and outcomes. Oxford Review of Education, 25(1/2), 231-250.

Horlacher, R. (2004). Bildung: A construction of a history of philosophy of education. Studies in Philosophy and Education, 23, 409-426.

Hüfner, K., Meyer, J., \& Naumann, J. (1987). Comparative policy research: A world society perspective. In M. Dierkes (Ed.), Comparative policy research: Learning from experience (pp. 188-241). New York: St. Martin's Press.

Khondker, H.H. (2000). Globalization: Against reductionism and linearity. Development and Society, 29(1), 17-33.

Kuhn, T.S. (1962). The structure of scientific revolutions. Chicago: University of Chicago Press.

Luther, M. (1983). Von weltlicher Oberkeit, wie weit man ihr Gehorsam schuldig sei (1523). In H.-U. Delius (Ed.), Martin Luther: Studienausgabe. Band 3 (pp. 31-71). Berlin: Evangelische Verlagsanstalt Berlin. (Original work published 1523.)

Lyotard, J.-F. (1984). The postmodern condition: A report on knowledge. Minneapolis: University of Minnesota Press. (Original work published in French 1979.)

Meyer, J.W. (1980). The world polity and the authority of the nation-state. In A. Bergesen (Ed.), Studies of the modern world-system (pp. 109-137). New York: Academic Press.

Meyer, J.W., Boli, J., \& Thomas, G.W. (1987). Ontology and rationalization in the Western cultural account. In G.M. Thomas, J.W. Meyer, F.O. Ramirez, \& J. Boli (Eds.), Institutional structure: Constituting state, society, and the individual (pp. 12-38). Newbury Park, CA: Sage.

Meyer, J.W., Boli, J., Thomas, G.W., \& Ramirez, F. (1997). World society and the nation-state. American fournal of Sociology, 103(1), 144-181.

Meyer, J.W., Drori, G.S., \& Hwang, H. (2006). World society and the proliferation of formal organization. In G.S. Drori, J.W. Meyer, \& H. Hwang (Eds.), Globalization and organization (pp. 25-49). Oxford: Oxford University Press.

Meyer, J.W., \& Jepperson, R.L. (2000). The "actors" of modern society: The cultural construction of social agency. Sociological Theory, 18(1), 100-120.

Meyer, J.W., \& Ramirez, F.O. (2000). The world institutionalization of education. In J. Schriewer (Ed.), Discourse formation in comparative education (pp. 111-132). Frankfurt: Peter Lang.

Meyer, J.W., \& Rowan, B. (1977). Institutionalized organizations: Formal structure as myth and ceremony. The American fournal of Sociology, 83, 340-363.

Meyer, J.W., \& Rowan, B. (1978). The structure of educational organizations. In J.W. Meyer and Associates (Eds.), Environments and organizations (pp. 78-109). San Francisco: Jossey-Bass. 
Osterwalder, F. (1992). Condorcet: Instruction publique und das Design der Pädagogik als öffentlich-rechtliche Wissenschaft. In J. Oelkers (Ed.), Aufklärung, Bildung und Öffentlichkeit (28. Beiheft der Zeitschrift für Pädagogik) (pp. 157-194). Weinheim: Beltz.

Osterwalder, F. (2003). Die Heilung des freien Willens durch Erziehung. Erziehungstheorien im Kontext der theologischen Augustinus-Renaissance im 17. Jahrhundert. In J. Oelkers, F. Osterwalder, \& H.-E. Tenorth (Eds.), Das verdrängte Erbe. Pädagogik im Kontext von Religion und Theologie (pp. 57-86). Weinheim/Basel: Beltz.

Osterwalder, F. (2006). Die Sprache des Herzens. Konstituierung und Transformation der theologischen Sprache der Pädagogik. In R. Casale, D. Tröhler, \& J. Oelkers (Eds.), Methoden und Kontexte. Historiographische Probleme der Bildungsforschung (pp. 155180). Göttingen: Wallstein.

Overesch, A. (2007). Wie die Schulpolitik ibre Probleme (nicht) löst. Deutschland und Finnland im Vergleich. Münster: Waxmann.

Pocock, J.G.A. (1962). The history of political thought: A methodological enquiry. In P. Laslett \& W. Runciman (Eds.), Philosophy, politics and society (second series), (pp. 183-202). Oxford: Oxford University Press.

Pocock, J.G.A. (1975). The Machiavellian moment: Florentine political thought and the Atlantic Republican tradition. Princeton, NJ: Princeton University Press.

Pocock, J.G.A. (1987). The concept of a language and the métier d'historien: Some considerations on practice. In A. Pagden (Ed.), The languages of political theory in earlymodern Europe (pp. 19-38). Cambridge: Cambridge University Press.

Ramirez, F., \& Boli, J. (1987). The political construction of mass schooling: European origins and worldwide institutionalization. Sociology of Education, 60, 2-17.

Saussure, F. de (2006). Writings in general linguistics. Oxford: Oxford University Press.

Skinner, Q. (1988a). Meaning and understanding in the history of ideas. In J. Tully (Ed.), Meaning and context: Quentin Skinner and his critics (pp. 29-67). Princeton, NJ: Princeton University Press.

Skinner, Q. (1988b). A reply to my critics. In J. Tully (Ed.), Meaning and context: Quentin Skinner and his critics (pp. 231-288). Princeton, NJ: Princeton University Press.

Suarez, D.F., \& Ramirez, F. (2004). Human rights and citizenship: The emergence of human rights education. CDDRL Working Paper, Stanford Institute for International Studies. Retrieved May 8, 2009, from http://cddrl.stanford.edu/publications/ human_rights_and_citizenship_the_emergence_of_human_rights_education.

Tröhler, D. (2006). Max Weber und die protestantische Ethik in Amerika. In J. Oelkers, R. Casale, R. Horlacher, \& S. Larcher (Eds.), Rationalität und Bildung: Studien im Umkreis von Max Weber (pp. 111-134). Bad Heilbrunn: Klinkhardt.

Tröhler, D. (2008). The educationalization of the modern world: Progress, passion, and the Protestant promise of education. In P. Smeyers \& M. Depaepe (Eds.), Educational research: The educationalisation of social problems (pp. 31-46). Dordrecht: Springer.

Tröhler, D. (2009a). Between ideology and education: The curriculum of uppersecondary education. Fournal of Curriculum Studies, 41, 393-408.

Tröhler, D. (2009b). Curriculum, languages, and mentalities. In B. Baker (Ed.), New curriculum bistory (pp. 97-117). Rotterdam: Sense Publishers.

Tröhler, D. $(2009 \mathrm{c})$. Beyond arguments and ideas: Languages of education. In P. Smeyers \& M. Depaepe (Eds.), Educational research: Proofs, arguments and other reasonings (pp. 9-22). Dordrecht: Springer.

Tröhler, D. (2010, in press). Harmonizing the educational globe: World polity, cultural features, and the challenges to educational research. Studies in Philosophy and Education, 29.

Tyack, D. (2003). Seeking common ground: Public schools in a diverse society. Cambridge, MA: Harvard University Press. 
Weber, M. (1930). The Protestant etbic and the spirit of capitalism. New York: Charles Scribner's Sons. (The first English translation was published by Unwin Hyman, London \& Boston, 1930, based upon the second German edition of 1920. The first German "edition" was two essays published in 1904 and 1905.)

Weber, M. (1950). Max Weber. Ein Lebensbild. Heidelberg: Lambert Schneider. (First published 1926.)

Weick, K.E. (1976). Educational organizations as loosely coupled systems. Administrative Science Quarterly, 21(1), 1-19.

Weigel, T.M. (2004). Die PISA-Studie im bildungspolitischen Diskurs Eine Untersuchung der Reaktionen auf PISA in Deutschland und im Vereinigten Königreich. Diploma thesis at the University of Trier. Retrieved May 12, 2009, from http://www.oecd.org/ dataoecd/46/23/34805090.pdf. 